\title{
Between the Walls of Recognition, a Philosophical Analysis of the Film The Class (Entre les Murs)
}

\author{
By Kobi Assoulin*
}

\begin{abstract}
This paper discusses the film The Class (Entre les Murs) from a philosophicalcultural point of view. The paper argues that, contrary to an intuitive interpretation of the film, an educational failure is performed by the class teacher, which mainly is due to a lack of reflection on and consciousness of the discourse practices within the class. These practices negate the student's concept of self or at least exemplify the lack of such an active acknowledgement. All this, of course, causes a crisis up to a failure of teacher-students' relationships. By analyzing scenes from the film, using Hegel's concept of mutual recognition, and his model of master-servant, the paper shows how the teacher tragically fails. All this with regard to the conceptual discourse set up by thinkers like G. F. Hegel, Plato, F. Nietzsche, A. Honneth, S. Hall, C. Taylor, H. Bloom and P. Bourdieu.
\end{abstract}

Keywords: Hegel, Honneth, Master-slave, Recognition, Respect.

Laurent Cantet's film The Class (Entre les Murs ${ }^{1}$ ) describes one school year in a suburban school in Paris. There we meet Mr. Marin - a young, middle class and intelligent teacher - and his class students - mostly from third-world backgrounds, many of them sons and daughters of African immigrants. The central topic of this film is the encounter between the class teacher, Mr. Marin, and his students, and the way this encounter shapes their developing relationships within the class walls.

The first feeling I had when watching it was that of deep admiration for the teacher. There is no escaping his devotion and care, or his belief in his ability, role and educational vocation. None of this is relinquished in the face of a challenging heterogeneous class, whose personal histories and the socio-economic environments they come from are so difficult. However, after watching this film several times, the Sisyphean nature of his educational journey all along that year permeates the film, and even more strongly, a sense of failure and despair as to the way Mr. Marin navigates his class. I claim that this failure is a result of the teacher's lack of "recognition relations" with his students, as I will uncover in this paper. My aim is, of course not merely to examine this specific film, and this specific teacher, but to indicate a broader phenomenon in possible teacher-student relationships.

Marin's figure and plot mirrors Aristotle's classic attributes of tragedy from The Poetics. As such, Marin, as the protagonist, starts the school year

\footnotetext{
* Lecturer, Oranim College of Education, Israel.

${ }^{1}$ That is "Between the Walls" in English. I believe that this title captures the essence of what this film is about.
} 
happy and full of confidence, however the film ends with a personal and pedagogical crisis. Aristotle's tragic hero as "a man not pre-eminently virtuous and just, whose misfortune, however, is brought upon him not by vice and depravity but by some error of judgement" (McKeon 1947: 640) suits Marin's character and shows his downfall to be the result of a series of educational mistakes. As a hero he fails not because he is an immoral person but because he is an imperfect human being, unreflectively manifesting the flaw of hubris. Not only that, as Aristotle posits, what empowers tragedy is the fact that between the evil maker (the hero) and his victims, there are prior deep caring relations, and after all, teacher-student relationships mirror those of father-child.

I claim that many of its major scenes explore this question of recognition, and even if these gestures and practices are often merely tacit and in need of interpretation, they form the axis of the teacher-student relationships. The failure the teacher faces, as the film ends, is due to the teacher's emotional obtuseness, not because of lack of proper intentions, lack of care, or lack of intelligence, but because he is not properly reflecting on the way he acts. He lacks an understanding of the dense meaning behind his seemingly trivial didactic class navigation. This lack of reflection prevents him from identifying the negative recognition relationship he creates between himself and his students.

What is then the focal scene for understanding Marin's critical mistake? What is that narrative mark that makes this plot? In one of the opening scenes of the film (Entre les Murs 7:34) a French lesson is taking place. The teacher asks his students to explain the meaning of the following words which are written on the blackboard: "sarcasm", "arrogance" and "hubris"2. The students' answers are lacked and ludicrous in terms of literacy and are answered by the teacher, without him being aware of the irony, mainly with: "sarcasm", "arrogance" and "hubris". This, as will be shown, is what accompanies most of the teachers' behavior throughout the film, his encoded behavior will be decoded inappropriately, and the students' perceptions of themselves will be also constructed accordingly. All of this occurs, and here lies the tragedy, without him being aware of it. For example, when Marin ridicules one of the student's answer without understanding that while for him it is considered an act of humor, for that student it might be considered an act of ridicule and even humiliation. As it is we well known, power tends to corrupt in many ways and the teacher, who holds power, without realizing it and without being aware of it, falls into this trap: the human voice of hubris. Thus, perceiving this film as a kind of tragedy indicates not only the private fall of Marin's but the danger that awaits any teacher.

It is important to emphasize that negative recognition practices, such as "condescension", "sarcasm" and "arrogance" do not necessarily eliminate the existence of positive practices such as "care" and "concern" and "support". Accordingly, in the film Marin definitely shows care, dedication

${ }^{2}$ Quotes from the movie, and references, are taken from its English translated version: The Class. 
and, from time to time, willingness to withdraw from the formal educational position toward an informal and extracurricular one. This is a major reason for the dissonance of the viewers' experience, which makes it difficult to understand his failure. Not only this, I would like to emphasize again, these negative recognition practices do not necessarily designate mental awareness and intention; the intention one has in performing and delivering a message is not what determines its meaning but rather the way it is publicly deciphered. In this we are following Charles Sanders Peirce's famous pragmatic maxima: "Consider what effects, which might conceivably have practical bearings, we conceive the object of our conception to have. Then, our conception of these effects is the whole of our conception of the object" (Peirce 1995: 44). The meaning of an action depends on its practical bearings, not upon its conceptual intention, motivation or awareness. This should not be interpreted as a reason to pardon a person, but on the contrary, to emphasize that a person should be aware and thus responsible for the way his behavior and utterances may be interpreted.

To understand the sources for this tragedy I would like to be assisted with the concept of mutual recognition as it was developed by G.F. Hegel. This model of recognition was originally developed in Hegel's famous Phenomenology of Mind (Hegel 2001). There, Hegel discusses the way selfconsciousness comes into being, however, unlike Kant's static and a-priory model of the self, Hegel revolutionary insight is by offering an intersubjective and dialectic model for this. Thus, before the dialectic individuals are conceived as pure desire which is aimed to achieve "self-certainty" through overcoming [consuming] an object or "other"....in order to establish its own self-standing independence", however, what humans are in need is an "object that brings about this negation within itself without ceasing to be an object" (Wood 1991: 84). This futile process can be stopped when confronting the Other, only then: "Self-Consciousness exists in itself and for itself, in that, and by the fact that it exists for another self-consciousness; that is to say, it is only by being acknowledged or 'recognized'" (Hegel 2001: 64). However, this revelation exposes the 'I' as being dependent on the 'Other': "First it has lost its own self, since it finds itself as another being; secondly, it has thereby sublated that other, for it does not regard the other as essentially real, but sees its own self in the other". The Other becomes not only an opportunity but a threat, so, "It [the I] must cancel its other self...First, it must set itself to sublate the other independent being, in order thereby to become certain of itself as true being; secondly, it thereupon proceeds to sublate its own self, for this other is itself" (Hegel 2001: 65). As this process is mutual, what is created is a mutual struggle, as for each 'I' the Other becomes a threat for his selfcertainty.

What comes out of this phase, in this dialectic, is a battle where "each must aim at the death of the other, as it risks its own life thereby". However, it should be emphasized, this new phase is not just an outcome, it is a new level and means for attaining empowered self-consciousness. As Hegel highlights this: "They must enter into this struggle, for they must bring the 
certainty of themselves, the certainty of being for themselves to the level of objective truth, and making this a fact both in the case of the other and in their own case as well. And it is solely by risking life that freedom is obtained" (Hegel 2001: 66). What comes from Hegel's dialectic is a deep understanding as to the way inter-subjectivity plays a major role in constituting our selfhood. Albeit, this should not be understood as some kind of natural social process, but as Pippin emphasizes as an on-going process aiming for a "practical achievement of some sort. Such a relation must be understood as the result of an attempt, never as it certainly seems to be, as an immediate presence of the self to itself, and it often requires some sort of striving, even struggle" (Pippin 2011: 14). That is to say, it demands accepting struggle for recognition to be an important and even a necessary part of building dynamically a selfhood. This battle ends only when one of the parties chooses life over self-consciousness, and thus he becomes the servant (bondsman) while the other becomes the master (lord) (Hegel 2001: 67). However, such a recognition is one-sided, unequal,) and noncooperative and by itself unstable (as they mistrust each other). Thus, this dialectic exposes us to our limited omnipotence of the other, and vice versa. As Hegel declares, what is needed is: "Ego that is "we", a plurality of Egos, and "we" that is a single Ego"(Hegel 2001: 64); what is needed is mutual recognition where each party gives up being in total freedom, while accepting his dependence on another. As we can see Hegel's revolutionary model refuses taking human-being selfhood as static or as a finished project due to some biological, biographic or any psychological structure. That is, selfhood is constituted dynamically, it is a "movement of recognition that forms the basis of an ethical relationship between subjects" and thus "consists in a process of alternating stages of both reconciliation and conflict" (Honneth 2005: 17)

Hegel's discussion helps us to understand that struggles, and the film is full of them, are not just a question of power and winning, they might be a necessary part of individuals seeking recognition. They express the way selfhood is dynamically and continuously shaped, and so as to teacherstudents relationships this process should be taken into consideration.

So, following Hegel's famous model of master-slave, and Mead's concept of The generalized other, the German sociologist Axel Honneth reflects on the way subjectivity is dialectically shaped, as non-ending and on-going phenomenological encounters between the self and significant others (Honneth 2001, Honneth 2005). Though Honneth follows Hegel's line of thought, he changes Hegel's abstract and metaphysical discourse for one that is post-metaphysical and practice-based. Honneth points how our daily lives are filled with expressions and gestures that, beyond their instrumental interests, are dialogical and performative; they express the way we perceive the Other, and in that way this Other constructs his self-image in response. Thus, the student who raises his hand, requesting to answer a question asked by the teacher, is not only expressing an instrumental urge to give an answer - as the class is a space of knowledge - but also an existential need for self-assurance and visibility. And so, if conversely, this 
student raises his hand unendingly, without being given permission to answer the question, the opposite sense of being will evolve: being invisible, being transparent. What makes this more significant is the fact of this being not an isolated event, but part of an on-going process between teacher and student. Thus, this sense of invisibility might become malignant and destructive.

In his theory Honneth presents three levels of recognition as performative speech acts. The first one is purely identification; for example, a teacher who reads the students' names when starting the day. The second level of recognition carries an expressive-narrative, even performative message, telling the addressee "I acknowledge your worth and thus I am willing to be for you in certain way". Finally, the third level of recognition expresses not only a will to do something, but also a willingness to sacrifice personal interests for the sake of the addressee. It must be emphasized that these practices of recognition do not always declare themselves to be so; many times they seem to be trivial and instrumental, yet they still carry a deep dimension of recognition. Thus, if we take personal computers as an example, in most cases these computers have the option to switch from one language to another (as we are all familiar in windows OS with the language tags down on the left side of the screen: "EN" (for English), "AR" (for Arabic), "HE" (for Hebrew), and so on). So, public institutions which enable switching in this way from language to language actually express, ethically and politically (and not just technically), the visibility and recognition they are giving to different language communities. Let us consider another trivial example: small children who cannot reach the toilet door handle in their kindergarten, which is unreflectively placed for adult convenience, not only they have practical difficulties, but they also sense a lack of recognition; they receive a message that "these spaces naturally belong to the adults". Another example, though a positive one, babies whose mother smiles at them not only receive a message of happiness, but also feel they are recognized, loved and worthy of attention(Stern 1977: 18-19). These micro examples are important because they show how continual and pervasive the concept of recognition is, even when it is tacit. We meet it through objects (as these, like the door handle in the above example, carry social and cultural meanings) and significant others (parents, spouse, partners, colleagues, managers and so on) in many life circles and time spans.

Thus, following the scene where "condescension", "sarcasm" and "arrogance" are presented, another word on the board deserves attention: 'Austrian'. Consider the way Marin treats the state of Austria. He asks one of the students for a description of that state, and after this student describes is the way he does Marin shakes him off and responds: "Austria is not a very important state; an Austrian is a resident of Austria. It is a very small state, we can skip it" ${ }^{3}$ (Entre les Murs 10:00). Continuing this scorn he rhetorically asks - accompanying this by dismissive body gestures - if there are any famous Austrians - implying it has made no real contribution to the world - however surprised when a student insists and names Mozart to be

${ }^{3}$ Emphasis is mine. 
one. Though, as I wrote above, maybe Marin's intention in these remarks is encoded with just humor and wit they are nonetheless in danger of being decoded as condescending and sarcastic. In his classic paper "Encoding, Decoding" Stuart Hall points to the possible gap between the way a certain message (intention) is encoded - by its addressor - to the way it is decodes by the addressees - the audience. That is:

The codes of encoding and decoding may not be perfectly symmetrical. The degrees of symmetry - that is, the degrees of "understanding" and "misunderstanding" in the communicative exchange - depend on the degrees of symmetry/asymmetry (relations of equivalence) established between the positions of the "personifications", encoder-producer and decoder-receiver. But this in turn depends on the degrees of identity/ non-identity between the codes which perfectly or imperfectly transmit, interrupt or systematically distort what has been transmitted. The lack of fit between the codes has a great deal to do with the structural differences of relation and position between broadcasters and audiences, but it also has something to do with the asymmetry between the codes of "source" and "receiver" at the moment of transformation into and out of the discursive form. What are called "distortions" or "misunderstandings" arise precisely from the lack of equivalence between the two sides in the communicative exchange. (Hall 2006: 166)

So, if we take this to refer to Marin's sarcastic remarks toward his students - remarks we are exposed to all along the film - these are deciphered through an envelope of dialog, humor and so on. From Marin's point of view - or intention - this could be the case, however they are deciphered differently by the addresses (students). In decoding these messages they integrate interpretational factors like existing power relations (the teacher as an authority), emotional relations (as suspicion, or mistrust) and cultural positions (as being an emigrant vs. being a "native"). So, a student is well aware that he is allowed to be witty but only up to a certain point beyond he might be punished, he knows that the right to determine the "last word" is given to the teacher only, and so on. Thus, "production conditions" as they are perceived by the teacher are not the same as they are perceived by the students and obviously different meanings are given to the same event. If we take, as an example, Marin's attitude towards one of the students, Boubacar. As we can see, all along the film, Marin makes a lot of jokes when referring to him, and stings him a lot as to his class behavior. For Marin it may be only a way for bringing some humor to the class, for Boubacar however, and the other students, it might be taken as kind of belittlement, humiliating, setting him in that image of the class clown,

Another example of educational lack of sensitivity is the scene (Entre les Murs, 11:24) in which Marin writes a sentence on the board to show the use of the word "succulent": "Bill ate a succulent hamburger", which causes a stir within the class. One of the students wants to know why Marin chose such a western dish, and another student asks, "Why 'Bill?"' After all the 
most of the class are immigrants, so why not choose an African name for the subject's name in the above sentence? Marin, instead of dealing with the hegemonic meaning of his choice, insists on preserving it without any willingness to discuss its cultural-political presumptions, when he could have used his example to deal with the way proper names function as linguistic capital (Bourdieu 1995, 80-81) is not just a pedagogical one, missing the opportunity for discussion of hegemony and multiculturalism; it is also an existential error - the lack of giving recognition to the students' need to bring their particular culture and personal identity to the fore. As Marin follows Hegel model of master-servant, in which the struggle for recognition is taken to be a win-lose situation; Marin demands the Other's recognition (in the scene mentioned it is Khoumba) of him as an authority via giving up her self-concept. Marin fails in not recognizing Khoumba's struggle as a necessary phase in Hegel's Master and Slave: the achievement of recognition. Putting it in a blunt way, teacher-student struggles should not be necessarily avoided, and if they are taking place they should be interpreted and tolerated accordingly, they are part of the whole dialectic. The Importance of aggressive struggle is also identified in Donald Winncot's classic psychological paper: "The use of an object and relating through identification" (Winnicot 1969). As he discusses the child's relation to his mother-object he writes as following:

"The subject says to the object 'Hullo object', 'I destroyed you', 'I love you', 'you have value for me because of your survival of my destruction of you.' ... it is the destruction of the object that places the object outside the area of the subject omnipotent control. In these ways the object develops its own autonomy and life. .... In other words, because of the survival of the object, the subject may now have started to live a life in the word of objects" (121).

So, the child-student tests his teacher by opposing him violently, actually asking him if he can contain his destructiveness while not losing his love, and only so he gains recognition for his self-value from his teacher. Aggression is not just a sign or an expression of violence against reality but it might be part of a recognition process (Winnicot 1969: 124-125). Only through putting the Other into a test, demanding him to contain his violence, he gains his "objective truth" (Hegel 2001: 66).

Marin fails in understanding that the art of education demands from a teacher what Nietzsche termed The Bestowing Virtue (Nietzsche ). There, Nietzsche calls for his disciples (students) to oppose him, to create themselves through opposing their father figure:

Indeed, I counsel you to go away from me and guard yourselves against Zarathustra! And even better, be ashamed of him! Perhaps he deceived you. The person of knowledge must not only be able to love his enemies, but to hate his friends too. One repays a teacher badly if one 
always remains a pupil only. And why would you not want to pluck at my wreath? (59)

Like Winnicot, Nietzsche understands that a necessary condition for a true student to create himself, as a person, is to struggle against his teacher.

Not only this, Marin's failure to see his students as they are, comes out of his insistence to look at them in a certain way; "their" invisibility is created out of a shadow that lies over them. It comes from Marin's unwillingness to put his perception of himself, his extended self, under review. In using the term 'extended self' I refer to the fact that it is not only Marin as a private person, as a certain teacher, but as a person who is the product of many life worlds. That is, the way his social biography is reflected in his teaching, the way he takes himself to be a representative of what is right and wrong from the school's point of view, as a representative of the educational system, and as a representative of the French bourgeoisie and the Western culture. Metaphorically, for his students Marin is what Harold Bloom termed a strong poet (Bloom 1997). Marin should acknowledge that the students' opposition to him expresses the way they are asked to embrace not a single person but " embrace the whole of her or his family romance as poet", as "True poetic history is the story of how poets as poets have suffered other poets, just as any true biography is the story of how anyone suffered his own family - or his own displacement of family into lovers and friends" and thus every new poem, culturally speaking, "is a misinterpretation of another poem. A poem is not an overcoming of anxiety, but is that anxiety" (94). Thus, the students' struggle, as black emigrants living in white France, is an expression of their anxiety for making their own poem against the poem of France, expressed and represented through Marin.

Moreover, when this cultural data is brought within the class walls, and when its validity is questioned by the students, it is easily rejected and overruled. After all, one cannot expect from a youngster to articulate a clear position, with its theoretical and comprehensive foundation. In a way, it is the teacher's function to posit or advance such an articulation process. For example, testing, together with the students, the cultural presumptions within the sentence we presented above; the way such a use manifests hegemony and power, the way sociolinguistic analysis helps understanding how language has meanings which go beyond the semantic ones. All of this requires a knowledge base and epistemological capacities beyond the students' current abilities. However, power relations are such that the critical possibility is conditioned by the authority: the teacher and the system (Giroux 1997: 122-126, Bourdieu 1995: 60-71). Marin chooses not to put this sentence example up for debate, as by doing so he would put the internal power relations to test. Thus, he betrays his students in the following ways:

- Epistemologically. He is not allowing interpretive options to be raised. As Giroux writes (following and citing Scholes): 
"Interpretation means reading a text along with a variety of diverse interpretations that represent a second commentary on the text. At issue here is the pedagogical task of helping students to analyze texts within "a network of relations with other texts and institutional practices", as to make available to all students "the whole intertextual system of relations that will finally include the student own writing" (Giroux 1997: 148) ${ }^{4}$. This epistemological betrayal is not by blocking a certain interpretative option, but by blocking the fundamental option, and legitimacy of disputing.

- Ethically. He is denying them the privileged option of being an interpretative subject. And after all, as we learned from Levinas: "One can, to be sure, conceive of language as an act, as a gesture of behavior. But then one omits the essential of language: the coincidence of the revealer and the revealed in the face, which is accomplished in being situated in height with respect to us-in teaching" (Levinas 1992: 67). After all, interpretation sets itself in front of another interpretation, and through this the 'I' sets himself as a similar Other, as a face. Marin's decision prevents and escapes what Giroux termed border pedagogy, as this: "offers the opportunity for students to engage the multiple references that constitute different cultural codes, experiences, and languages. This means educating students not only to read these codes critically but also to learn the limits of such codes, including the ones they use to construct their own narratives and histories" (Giroux 1997: 147). Marin's choice is between giving the students a voice and between following the formal course of the lesson. It is a decision related to the authority guiding him: should he respect the state, or the student in front of him? Power or morality?

- Empathetically. What was needed in the above example (the "hamburger" sentence) is the ability and will to stop and postpone verdict, to understand what is bothering the student who asked the question, and why the other students almost automatically joined in. This unwillingness to enter a process of empathy is the basis for not giving recognition, as recognition demands giving space to the other and narrowing your own. Here, it is expressed by Marin's unwillingness to listen, to break the formal educational process and curriculum; by not allowing the students to be the center of the class territory, even for a short moment, and by his unwillingness to become a guest in that territory.

In the next scene I would like to discuss the students' resistance, and even rejection, as to the necessity of one of the complex tenses in French, the subjunctive (Entre les Murs 15:51). Students dispute about the necessity of learning this, as this tense has no daily use, and when it is used is done mainly by the elitist-bourgeois class to express its intellectual superiority

\footnotetext{
${ }^{4}$ The embedded quotation marks are originally written as they cite Robert Scholes Textual Power (Yale Univ. Press 1985).
} 
over the other societal strata; a matter of snobbism as one of the student calls it. Interestingly, a similar argument is used by the famous sociologist Pierre Bourdieu: "For Example on the educational market, the imperfect subjunctive had a high value in the days of my teachers, who identified their professional identity with using it ... Nowadays that would provoke smiles and can't be done in front of a student audience, unless you emit a metalinguistic sign to show that although you're doing it you could equally well no do it"(1995: 79) to show the way the cultural-linguistic capital is used to base social distinctions among teacher and students. You would expect from Marin as an educator, highly intelligent and well-educated person that he is, to welcome such a critical, perceptive and original insight, to divert the course of that lesson for a socio-linguistic discussion, yet here again, he misses this opportunity. Though he finally admits that the tense is used by "snobs", he still fights for the legitimacy and validity of what he is doing while annulling the legitimacy of their perspective. He takes their reaction only as an educational crisis, just a revolt, and a threat, regarding his intellectual authority, certainly not as an opportunity for bestowing trust on them; to recognize their place as autonomous thinking subjects. To quote Bourdieu, as you would think that he, too, refers to this film:

"[c]ommunication in a pedagogic authority presupposes legitimate emitters, legitimate receivers, a legitimate situation and a legitimate language. It needs a legitimate emitter, that's to say someone who recognizes the legitimate laws of the system and who is, by the virtue of that, recognized and coopted. It needs addresses recognized by the emitter as worthy of receiving, which presuppose that the emitter has a power of elimination, that he is able to exclude those who 'should not be there'. But that is not all: it needs pupils who are ready to recognize the teacher as teacher, ... it also requires, ideally, the receivers should be... homogenous in knowledge of the language and recognition of the language, and that the structure of the group should not function as a system of a censorship capable of forbidding the language that has to be used" (Bourdieu1995:66) ${ }^{5}$.

This dispute actually is kind of a micro-example to a long standing confrontation between philosophy and politics as it is discussed by Hanna Arendt in "Philosophy and Politic" (Arendt 1990). There, Arendt discusses the way Socrates makes the doxa his main concern while Plato "designed his tyranny of truth, in which it is not what temporarily good, of which men can be persuaded, but eternal truth of which men cannot be persuaded, that is to rule the city" (78). Educationally, the Socratic political project was aimed for a public sphere - as the class is - which is not aimed in the authoritarian truth - as a teacher might be - but in what "Socrates himself called maieutic, the art of midwifery, he wanted to help others give birth to what they themselves thought anyhow, to find the truth in their doxa" (81). This is shown in Socrates' dialectical elenchus, which dialogically is a

\footnotetext{
${ }^{5}$ emphasis is mine.
} 
"search for moral truth by adversary argument in which a thesis is debated only if asserted as the answerer's own belief, who is regarded as refuted if and only if the negation of his thesis is deduced from his own beliefs" (Vlastos 1983: 37). The power of the Socratic elenchus lies not within his technical ability to reach truth, but in its educational properties of giving mutual recognition while preserving mutual respect. So, as we read Socrates' dialogs we can hear both voices, both are on an equal level, both are obligated to say what they really think, to be courageous and speak what they think (Seeskin 1984: 181). Thus, what the elenchus is aimed for is "honesty, humility, and courage as it does with logical acumen: the honesty to say what one really thinks, the humility to admit what one does not know, and the courage to continue the investigation" (182). This is exactly what happens in the scene we discussed above! The teacher is asked for a kind of dialog; however he is unable to bring himself educationally in terms of honesty, humility and courage. Marin takes himself to be a representor of truth and power, as it represented in the scene by the formal educational curriculum, instead of putting it into question, that is, instead of recognizing Aristotle's communal friendship where a "community comes onto being through equalization" (Arendt 1990: 83).

As it can be seen, teacher-student relations cannot avoid one of the main properties entailed in recognition: the question of giving, and receiving, of respect. In "The politics of Recognition" Charles Taylor (1994) points to the way of modernity, especially the development of democracy and the social process of hierarchy nullifications, led to two major developments regarding the general concept of respect: First, the abolishing of the traditional concept of honor and secondly the establishment of dignity and respect over this. Thus, dignity is taken to be universal, intended for each human being and expresses that nucleus of basic humanity, to which everyone is entitled. In this we can find the rejection and denial of legitimacy of humiliation, abuse, shaming and so on, and the right for receiving basic material goods (shelter, food, basic health treatment and so on). Respect moves one step further in the provision of autonomy, material and intellectual conditions (such as free expression and education) for the flourishing of life. Honor, on the other hand, is nonegalitarian by definition; it aims to serve distinct individuals within a certain class or social category - a category which is taken to be worthier than others in some respect and on some occasions, at least. Thus, in traditional societies you will probably find the father as deserving honor. Sometimes this honor carries symbolic meaning and sometimes the benefits are real, socially, politically and even economically (Taylor 1994: 26-29). In a liberal society, where the Kantian ideal of impartiality dominates, we can only find formal echoes of the concept of honor. People will address their physician as 'Dr. ...', they will address the judge as 'Your honor', and perhaps their academic lecturer as 'Dr. ...'. This is of course not the way honor functioned in terms of power and actual revenues within traditional societies. A question then arises, what happens to the need of recognition with this socio-political shift from honor to respect and dignity? On one hand those 
whose honor is diminished now suffer from less recognition. On the other hand, as dignity and respect become much more egalitarian and universal, many people request, ask and even demand public recognition. Thus, if Hegel's model of master-servant exemplify humans primary need for recognition, the question that arises is how changed social practices and norms, including linguistic ones, affect our customary relations of recognition - like replacing 'Mr' for 'Sir' in modern-democratic societies (2627) - and the way people cope socially and psychologically with these changes. This is intensified as we deal with hierarchical and autonomous organizations submerged in an egalitarian modern-democratic culture. And so the modern subject falls prey to these opposing tendencies: the liberal which equalizes and flattens and mainly demands dignity and respect - and that of institutional and hierarchal roles which demands honor. Thus, we can find subject A expecting certain honor while subject B is not aware of it and thus does not give recognition and legitimacy to that expectation. Let us linger on the following scene- a typical class situation - in Entre les Murs (27:20), when one of the students, Khoumba, is asked to read from Anna Frank's Diary. She refuses and asks the teacher to give the task to another student. Confronted with this situation, Marin decides to make a public dispute out of it. Now, we can criticize him for his choice to handle this dispute in front of the whole class, but a more relevant question would ask about the "benefit" of such a public dispute for him. For Marin, this dispute is a firm request for accepting recognition from the class as an authority, not just as a knowledgeable authority, but in terms of governmental and even patriarchal authority as well. What we face here is a state of what Richard Rorty termed abnormal discourse, as each side uses a different vocabulary (Rorty 1981: 320-322). For Marin the issue is that of honor, and for Khoumba, the issue is that of dignity. Again, as in Hegel's master and servant, each person takes his need of recognition to be crucial, each demands self-assurance from the Other while assuming that such a selfassurance necessitates the Other to relinquish his own self, and from here this struggle deteriorates to a life - or- death situation. What intensifies this struggle is the fact we are not discussing a bi-polar environment but rather one that is tri-polar, the third one being the other members of the class. After all, as was shown by G. H. Mead, in his famous concept of the generalized other, the individual builds his or her behavior upon imagining the group expectations (Mead 1962: 154). For Khoumba, society is her class mates; these are her significant others and thus the generalized other. For Marin, on the other hand, his generalized other is much more expanded and less concrete, it is the class members but also wider circles, such as the teaching staff, his social class and finally the educational system, what builds a different telos for his behavior, and thus an unavoidable confrontation arises. For Khoumba, this is a test for her autonomy, while for Marin this is a test for his prestige and honor as a teacher. Though, they may use the same linguistic token ("respect"), in fact they use different social anchors and meanings. 
Following this confrontation Marin summons Khoumba for a meeting (Entre les Murs 37:2) and asks for her assessment notebook as he intends giving her a note of reprimand. However, conversation conditions are such that from the start, as in a Greek tragedy, the hero continues on the path to his downfall; not because he cannot perceive this but because he cannot do otherwise. Again we see the way Hegel's model is manifested, as each consciousness struggles for accepting the Other's recognition with no intention of relinquishing some of their selfhood for the sake of that other's mutual need of recognition. Even the physical setting gives no escape from the failure: an environment that reflects and shapes power relations, and thus fatalistically determines the possible outcomes for this dialog. First, the desk which stands between Marin and Khoumba, sets a "demilitarized zone", making this a war situation with its barriers. Following this, the way Marin sets his body above Khoumba, using an alarming voice and tone, creates a context that imprisons them both within definite roles. Lastly, when Khoumba refuses to give her notebook to him, Marin insists that she gives it to him, as this object demonstrates for students that they are under a constant gaze; their personality and private history is constantly recorded (Foucault 1995: 184).

But Marin is not satisfied by receiving the notebook he demands that it be served in a proper manner, one that exemplifies the honor he deserves. Again, it is not a bi-polar confrontation as they are witnessed by Khoumba's friends standing at the door, fulfilling, as in any Greek tragedy, the role of the Greek chorus. The peak of this master-servant struggle comes when Marin demands a "sincere" apology, spoken the "right" way, with the "right" feeling. Khoumba outwardly obeys him; however, when she walks away she spits out to Marin that there was no sincerity in her apology, thus expressing the failure of this honor giving practice to create an authentic and trustworthy behavior.

This pervasiveness of the concept of mutual recognition and respect for teacher-student relationships can be seen later on (Entre les Murs 45:50) when Khoumba, following the confrontation with Marin, writes him a personal letter. Before discussing its content it must be emphasized that this media of a letter has its internal logic. When one reads a letter, though he is the addressee, he is naturally blocked of the without the ability (as occurs in speaking) to cut off the interlocutor; it is also an intimate situation, which excludes others from gazing at you or being part of the situation; it restrains asymmetrical power positions, and generally it prevents a disruption of communication. And how does Khoumba start her letter? By raising the issue of respect she explains to Marin that respect has to be mutual, and that without this mutuality there is no future for any authentic respect, for mutual recognition. In this letter Khoumba struggles to explain and overcome the gap between their different perceptions of respect, thus making their abnormal discourse a little more normal through reaching an agreement on their basic vocabulary axioms. 
In conclusion, Entre les Murs is not a film about some imaginary class in Paris; it expresses real and significant situations, though they seem to be trivial, and even banal, between teacher and students. The dissonance, we as an audience experience, proves that qualities, positive in themselves, like will, educational faith, motivation, intelligence and hard work are not enough. The film conveys the centrality and even necessity of other qualities like recognition, mutual recognition, dignity, honor, and dialogic discourse, terms which are crucial for success in the art of teaching. Such a failure comes not from lack of motivation, lack of talent, lack of knowledge, lack of investment or lack of ethics; rather, it comes out of lack of brave and sometimes painful reflection. In fact, the positive and dedicated character of Marin only empowers this tragedy, and prevents us from finding an easy guilty. It is interesting that over the course of the years Marin asks all his students to participate in a pedagogical project where they express (through writing or through other means like photography) their self-portrait, actually to reflect upon their concept of the self. It is one of the few times, that as an audience, we witness an authentic and powerful practice of giving recognition from the teacher to his students. Ironically, and tragically, however, he forgets to embrace this educational practice as to himself and thus reflect, test, and question his own self-portrait as a teacher.

\section{References}

McKeon R (Ed) (1947) De Poetica. In Introduction to Aristotle, 622-667. NewYork: Random House Inc.

Arendt H (1990) Philosophy and politics. Social Research 57(1): 73-103.

Bloom H (1997) The Anxiety of influence. New-York: Oxford University Press.

Bourdieu P (1995) Sociology in question ( $2^{\text {th }}$ ed). London: Sage Publication.

Entre les Murs/The Class (2008) [Motion picture] Simon A, Benjo C., Lettelier B, Scotta C (Producers), Cantet L (Director)

Foucault M (1995) Discipline and punish: The birth of the prison. New-York: Vintage Books.

Giroux H (1997) Pedagogy and the politics of hope: Theory, culture, and schooling: a critical reader. Boulder, Colorado: Westview Press.

Hall S (2006) Encoding, decoding. In Media and Cultural Studies: key works M G Durham, DM Kellner, 163-173. UK: Blackwell Publishing.

Hegel GWF (2001) The phenomenology of mind. Translated by JB Baillie. Retrieved from http://bit.ly/2cleb32.

Honneth A (2001) Invisibility: On the epistemology of "recognition". The Aristotelian Society 75(1): 111-126.

Honneth A (2005) The struggle for recognition. Cambridge: Polity Press.

Levinas E (1992) Totality and Infinity. Pittsburgh: Duquesne University Press.

Mead GH (1962) Mind, self and society. Chicago: The University of Chicago Press.

Del Caro A, Pippin RB (2006) Nietzsche: Thus Spoke Zarathustra (Cambridge Texts in the History of Philosophy). Cambridge University Press.

Peirce CS (1995) How to make our ideas clear. In R Goodman (Ed) Pragmatism: A Contemporary Reader. New-York: Routledge. 
Pippin RB (2011) Self-consciousness: Desire and death in the phenomenology of spirit. Princeton, NJ: Princeton University Press.

Taylor C (1994) The politics of recognition. In A Gutmann (Ed) Multiculturalism. Princeton, NJ: Princeton University Press.

Rorty R (1981) Philosophy and the mirror of nature. Princeton, NJ: Princeton University Press.

Seeskin K (1984) Socratic philosophy and the dialog form. Philosophy and Literature 2(2): 181-194.

Stern D (1977) The first relationship: infant and mother. Cambridge, Mass: Harvard University Press.

Winnicot D (1969) The use of an object and relating through identifications. International Journal of Psycho-Analysis 50 (1969).

Wood AW (1991) Hegel's ethical thought. Cambridge: Cambridge University Press.

Vlastos G (1983) The Socratic elenchus. Oxford Studies in Ancient Philosophy 1: $27-58$. 
